\title{
Impresos novohispanos de 1821: ¿independencia o sujeción a España?
}

\author{
Manuel Ferrer Muñoz \\ INSTITUTO DE INVESTIGACIONES JURÍDICAS-UNAM
}

Se examinan las diferentes ideas sobre la independencia de Nueva España en la literatura panfletaria de la época, bajo la premisa de que el movimiento insurgente hispanoamericano no fue de levantamientos genuinamente populares, sino de revoluciones organizadas e impulsadas por algunos sectores cultos de las clases media y alta, por lo que los impresos producidos por esos grupos puede contribuir a la comprensión teórica de los motivos que impulsaron la lucha emancipadora.

OPINIÓN "PÚBLICA" E INDEPENDENCIA

$\Gamma$ a proclamación de independencia facilitó la difusión y traducción de obras de autores ilustrados y revolucionatios franceses e ingleses, de sus comentaristas, y de escritos divulgadores del constitucionalismo estadunidense que antes resultaba muy difícil adquirir en las librerías. ${ }^{1}$ Entre los lectores de estos impresos

1 Por supuesto existían otros conductos para el acceso a esas obras, muchas de las cuales se introducian y circulaban en Nueva España de modo fraudulento. Pérez-Marchand ha estudiado algunos de los mecanismos utilizados para no encontramos tan sólo a los legisladores de 1823-1824: hubo además un sector ilustrado de la población que se había familiarizado con esa literatura política y que se esforzó por propalarla a través de folletos o de publicaciones periódicas. ${ }^{2}$

No parece prudente, sin embargo, imaginar que el entusiasmo por esas ideas hubiera prendido conscientemente en estratos amplios de la sociedad, ni

burlar el control ejercido por las autoridades; veáse Pérez-Marchand, Dos etapas, 1945, pp. 92-98.

${ }^{2}$ Sierra, La Constitucion, 1983, pp. 45-51. 
que la propuesta emancipadora re vistiera un carácter popular, al menos en el sentido de que la gente común poseyera una percepción clara del hecho que aclamaban, incluso con frenesí, en calles y plazas, en tertulias y cafés. ${ }^{3}$

Este juicio, que ya expresara en su momento Javier Ocampo, se apoya en los escritos de la época, que transmiten una certeza incuestionable:

para los estamentos inferiores la independencia política de México no tiene ninguna consecuencia, por cuanto que su situación social seguirá la misma que cuando el dominio español. ${ }^{4}$

El querer independentista ni siquiera constituyó un aprecio predominante entre los criollos, la mayoría de los cuales eran burgueses acomodados y temerosos de los desórdenes sociales: sólo un grupo instruido, probablemente pequeño, ${ }^{5}$ participó de la admiración por los ideales republicanos estadunidenses y por el pensamiento jacobino francés.

Si en algo coincidieron todas las clases criollas, cultas o ignorantes, fue en la común atracción por un interés de estrechas miras que podríamos llamar -peyorativamente- "nacionalista": a todos apetecía ocupar los puestos de mando que dejarían vacantes los funcionarios españoles. ${ }^{6}$ Tal vez esto pro-

3 Ocampo, Las ideas, 1969 , pp. 53-58.

${ }^{4}$ Ibid., p. 270.

5 Pérez, en cambio, otorga mayor amplitud al sector de mexicanos cultos que trabó conocimiento con las obras francesas, no mucho después de su publicación en Europa; Pérez Marchand, Dos etapas, pp. 137-145.

${ }^{6}$ Rangel, Du bon, 1976, p. 100. porcione la razón de por qué se implicaron en el proyecto trigarante de 1821 elementos de las clases superiores que once años antes se habían mantenido al margen o aun en contra del movimiento insurgente, que nada seguro les deparaba.

La acusada distinción entre una minoría ilustrada y una mayoría iletrada ha conducido a algunos investigadores a formular la tesis de que los movimientos de independencia hispanoamericanos -incluido el de Méxicono fueron levantamientos genuinamente populares, sino "revoluciones políticas organizadas y propulsadas por las clases medias cultas y algunos grupos de las altas". Por eso, la comprensión teórica de las razones que impulsaron la lucha emancipadora puede basarse legítimamente en el examen de la literatura panfletaria que produjeron los grupos sociales más altos. ${ }^{7}$

Se precisa una última advertencia antes de entrar definitivamente en materia, y es que la folletería de 1821 es hija de las circunstancias incendiarias de ese año: publicada cuando la ruptura total con España era inminente o había sido ya realizada, fue concebicla para lograr que la opinión pública cristalizara en favor de la independencia. Y ese carácter instrumental implicaba, necesariamente, una fuerte dosis de "exageración deliberada de los vicios y de la maldad españoles", en abierto contraste con la idealización de América que, a los ojos de los panfletistas, encerraba una potencialidad sin límites. ${ }^{8}$

${ }^{7}$ Bachman, "Los panfletos", pp. 522-538, esp. 522-523.

8 Ibid., pp. 530-531. 


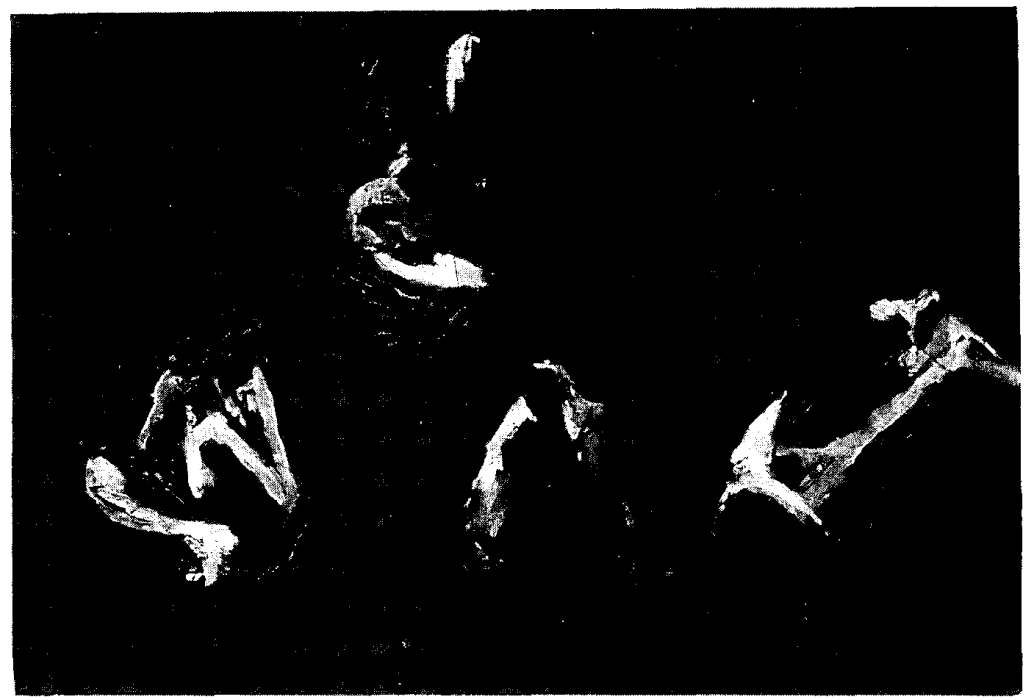

\section{LA "ANTESALA" DE LA INDEPENDENCIA}

La "suerte de las Américas" - título de una producción literaria impresa originalmente en Madrid y reproducida en México en 1820-9 era objeto de discusión pública sistemática al iniciarse la tercera década del siglo bajo los auspicios del régimen de libertades que pretendía sepultar el sexenio "absolutista" de Fernando VII.

El nudo gordiano de la especulación teórica sobre el futuro de los territorios americanos venía constituido por la difícil realización práctica del generoso enunciado de las Cortes, que definía las posesiones de América

9 J. V., Sobre, 1820, Fondo Lafragua de la Biblioteca Nacional de México (en adelante, LAF) 261. como parte integrante de la monarquía española. A fin de cuentas, ésta había sido la pretensión constante y frustrada de la corona de Castilla;

pero ¿de qué sirvieron estas declaraciones pomposas, hechas después de haber despojado a los americanos del dominio del país junto con la propiedad del suelo, y después de autorizar, o de tolerar cuando menos, que vivieran en servidumbre en poder de los encomenderos, bajo el destructor sistema de repartimientos o mitas, que en poco tiempo consumió la mayoría de aquella útil porción de nuestra especie? ${ }^{10}$

Era, pues, explicable la desconfianza de América cuando oía hablar de

${ }^{10}$ Ibid. 
una igualdad en la representación en Cortes, que venía desmentida por la vía de los hechos y por la adopción de medidas de fuerza.

Ciertamente, la crisis imperial ocupaba un lugar preferente en la agenda de los liberales, victoriosos desde que Fernando VII jurara la Constitución el 9 de marzo de 1820: la reorganización del ejecutivo efectuada el día siguiente incluía la creación de un Ministerio de Ultramar; y la Junta Provisional ${ }^{11}$ propuso unas cuantas medidas que habían de realizarse a corto plazo y que fueron admitidas con enmiendas de poca importancia: ${ }^{12}$ pero ni Fernando ni las nuevas autoridades estaban dispuestos a abandonar el recurso de la fuerza.

Las Cortes no emplazaron la cuestión americana entre sus prioridades, absorbidas tal vez por el denso programa de cambios en las estructuras politicas, económicas y sociales de la monarquía y por los problemas internos de la nación (radicalismo de las capitales de provincia versus conservadurismo del campo y del gobierno

11 La Junta Provisional Gubernativa se constituyó el 9 de marzo de 1820, después de una extraña asonada cuyos móviles nunca quedaron suficientemente aclarados; Gil, El trienio, 1980 , pp. 5-8.

12 Ese programa constaba de los siguientes puntos: instrucciones a los americanos para que prepararan las elecciones de sus representantes en las nuevas Cortes; manifiesto del rey sobre los beneficios del nuevo sistema para uitramar; cese del fuego; si los americanos declinaban el envío de diputados, que mandasen comisionados que expusieran sus deseos y medios para la reconcitiación; en algunas provincias, reunión de los mandos políticos y militares; Costeloe, $L a$ respuesta, 1989, p. 112. de Madrid): ${ }^{13}$ da la impresión de que permanecieron a la espera de los resultados que pudieran arrojar el retorno de las libertades y las negociaciones emprendidas. Partidarias indudablemente de una solución conciliadora, perdieron un tiempo precioso sin aportar un planteamiento de conjunto.

En el mes de mayo de 1821 pareció que, por fin, las Cortes decidían tomar cartas en los asuntos americanos. Después de la intervención de un diputado venezolano, el conde de Toreno sugirió el nombramiento de una comisión mixta de europeos y americanos encargada de entregar al pleno un plan de pacificación para los territorios de ultramar antes de que finalizase el periodo de sesiones. Aprobada la proposición de Toreno, al día siguiente quedó constituida la comisión con nueve diputados, de los cuales dos eran novohispanos (Alamán y Zavala).

Los trabajos de la comisión procedieron con rapidez y fueron seguidos de cerca por varios ministros del gobierno. Pero a fines de junio se desembocó en un callejón sin salida ante la decisión del Ministerio de suspender su juicio por considerar que "la opinión no se hallaba preparada para una resolución definitiva". ${ }^{14}$ Esta actitud del ejecutivo imposibilitaba a la comisión señalar los medios que debieran emplearse, ya que tal responsabilidad competía al Ministerio. Tenía, pues, que limitarse a procurar que

${ }^{13}$ Artola, España, 1968; Comellas, "El trienio", 1981, vol. XII, pp. $398-452$ (pp. 434-443).

${ }^{14}$ Exposición, 1821, LAF-678. El texto de la exposición se publicó también en México: Ramírez, Nada, 1821, LAF-254. 
se excite el celo del gobierno a fin de que presente a la deliberacion de las Cortes, con la mayor brevedad, las medidas fundamentales que crea convenientes, así para la pacificación justa y completa de las provincias disidentes de América, como igualmente para asegurar a todas ellas el goce de una firme y sólida felicidad. ${ }^{15}$

Para prevenir el riesgo de un definitivo colapso de la acción gubernativa y los consiguientes daños para las provincias de ultramar, tan sólo un día después de la lectura del dictamen de la comisión especial, los diputados que las representaban en las Cortes hicieron público un documento -que había elaborado Michelena- con objeto de mostrar al Congreso el estado de los asuntos americanos y de proponer medidas que restablecieran la tranquilidad y aseguraran la conservación de las tierras de América. La idea de elaborar la exposición fue adoptada después de una reunión en casa del diputado mexicano Francisco Fagoaga. De acuerdo con la versión de Zavala,

convinieron en presentar a las Cortes una exposición en que se manifestasen las razones de conveniencia política para hacer a las Américas las concesiones que exigían el estado de su virilidad y de su civilización. Fueron nombrados para formar la exposición los diputados Molinos del Campo, Navarrete y Zavala, y aprobada la presentaron a las Cortes en junio de $1821 .{ }^{16}$

15 Ibid.

16 Zavala, Ensayo, 1969, p. 95 . Véase también Rodríguez O., "The transition", 1994, pp. 97-132.
Entre los delegados de Nueva España que firmaron la Exposición se hallaban los mismos que habían promovido el Papel del 22 de enero de $1821,{ }^{17}$ con las únicas ausencias de Cañedo y de José María Couto, que presentó un proyecto de ley, con Ramos Arizpe, muy semejante en su contenido a las propuestas de la Exposición.

Según los redactores del texto, resultaban insignificantes los avances registrados desde principios de año en la tarea pacificadora de América: más bien parecía, incluso, que el deterioro se había agrandado al estallar, en Nueva España, una nueva revolución "de un carácter mucho mas temible que la anterior". Lo apurado del momento impulsaba más a la acción que a la meditación sobre las causas del descontento de América, ya archisabidas en sus rasgos fundamentales, y también era evidente, a esas alturas, que el empleo de la fuerza no producía el efecto deseado.

Los firmantes del documento no dudaban en señalar el aprecio de los americanos por la Constitución, al tiempo que observaban que "en el estado actual de cosas [la] consideran como una bellísima teoría que sólo en la península puede reducirse a práctica". La cuestión era cómo hacer operativo en América el texto constitucional, aunque para ello se precisara adoptar medidas que, en su literalidad, desbordasen las previsiones de la carta fundamental, algunas de las cuales se adecuaban muy deficientemente a la realidad americana: por ejemplo,

17 Papel 1821, LAF-955. Véase también Ferrer, La Constitución, 1993, p. 194. 
los mecanismos de control de los empleados públicos, el sistema electoral o la remisión bienal de diputados a las Cortes.

Después de indicar los obstáculos que la distancia entre ultramar y la península generaba en las tareas legislativas de los diputados, la seguridad del Estado, la fijación de ingresos en la Hacienda Pública y el ejercicio de los poderes ejecutivo y judicial, se justificaba por extenso el criterio adoptado de respetar, sí, el espíritu de la Constitución, sin sentirse obligados a someterse a disposiciones que más servían de estorbo que de provecho:

hemos creído que debíamos presentar medidas que en vez de contrariar los principios esenciales de la Constitución, no tienen otro objeto que remover los embarazos que impiden su establecimiento en América, y que dejando intactos los fundamentos del sistema, lo hagan efectivo en aquella gran parte de la monarquía. ${ }^{18}$

Seguían a esto quince proposiciones, algunas de las cuales eran aplicables sólo al virreinato novohispano. La idea básica que presidía el plan de reformas era la concesión de una amplia autonomía a América, que acercara a sus habitantes a los centros de toma de decisiones. Se postulaba la creación de tres secciones de Cortes, una en la América septentrional -con residencia en México- y dos en la meridional. En cada una de esas divisiones habría de instalarse una delegación que, en nombre del rey, ejerciera el poder ejecutivo a través de cuatro

\footnotetext{
${ }^{18}$ Exposición, 1821.
}

ministerios: Gobernación, Hacienda, Gracia y Justicia, y Guerra y Marina. También el Tribunal Supremo de Justicia y el Consejo de Estado deberían constituirse en tres secciones.

Además se concedía atención preferente a la aportación económica de Nueva España a la metrópoli: aquélla se obligaba a entregar a la península la suma de doscientos millones de reales en el espacio de seis años para contribuir al pago de la deuda exterior; se comprometía a destinar a la marina cuarenta millones de reales cada año, y se responsabilizaba del pago de toda la deuda pública contraída por el gobierno en su territorio. ${ }^{19}$

\section{EL RECHAZO DEL "ESPÍRITU DE PARTIDO" EN LOS IMPRESOS}

A pesar del escepticismo cada vez más difundido en 1821, el retorno al orden constitucional propugnado por los órganos escritos de expresión estuvo marcado en sus orígenes por sinceros deseos de conciliación, tales como los que había manifestado una Proclama de un americano a los insurgentes impresa en México en el mes de agosto de 1820 , cuyo autor - "El Americano liberal, J. V." - participaba de la presunta fe de Fernando en los instrumentos constitucionales como vehículo de pacificación, y destacaba la circunstancia de que en los medios públicos de la península se prefería el término de "disidentes" para designar

19 Gil, El trienio, pp. 31-32; Rodríguez, "The 'american question'", 1982, pp. 293-314 (pp. 304-305); Ladd, La nobleza, 1984, p. 187, y Costeloe, La respuesta, pp. 231-232. 
a los americanos descontentos, hasta entonces llamados "insurgentes".

Si "El Americano Liberal" empleaba esta denominación, lo hacía porque ese nombre era "el mas común y conocido hasta por ellos mismos, pero de ninguna manera por injuriar ni envilecer con él a mis paisanos". Las apatías y los temores que observaba entre sus conciudadanos a los pocos meses de que hubiera entrado en vigor la Constitución le movían a excitar su patriotismo y a fiarlo todo en la integridad del rey: "él ha jurado poco ha en manos del soberano Congreso de las Cortes, constituirse el defensor acérrimo de nuestra libertad, y nosotros guardarla y sostenerla para hacer este código inmortal". ${ }^{20}$

También ElMejicano Independiente parecía compartir el aprecio hacia la persona del rey español, y rechazaba la imputación de que los propugnadores de la emancipación hubieran negado la obediencia a Fernando VII:

pedimos solamente que se establezca y radique entre nosotros para estrechar más y más los vínculos de nuestra sumisión, queremos gozar de su real presencia para que la interposición de los mares no debilite los influjos benéficos de su augusto trono. ${ }^{21}$

Sin embargo, la perpetuación de los antagonismos entre europeos y 253.

${ }^{20}$ El americano liberal, Proclama, 1820, LAF-

${ }^{21}$ ElMexicano Independiente, 14 abril 1821, reproducido en García, "La prensa", 1974, vol. v, t. 2, pp. 492-493. Este periódico había aparecido por vez primera el 3 de marzo, escasamente nueve días después de la proclamación del Plan de Iguala. americanos, aun después de que recuperara vigor la Constitución en Nueva España, indujo a muchos panegiristas del nuevo régimen a clamar contra ese "espíritu de partido" que obstruía el aquietamiento. En busca de elementos de coincidencia entre unos y otros, se destacaba la común hostilidad al "gobiernoarbitrario y opresor que por nuestra desgracia ha oprimido a unos y otros tantos años". Desde ese prisma, la insurrección de 1810 no había tenido por móvil el odio al europeo, sino el "erróneo sistema de gobierno", y si los disidentes

creyeron justo y necesario declararle la guerra al europeo, fue no principalmente ni por destruirlo inspirados del odio, sino accesoriamente y en cuanto ellos juzgaron que vosotros os habíais de oponer con todos los posibles esfuerzos a sostener las miras de un tirano gobierno que pretendian destruir. ${ }^{22}$

\section{LOS "AGRAVIOS" INFERIDOS A LOS AMERICANOS}

Ni la llegada de nuevos tiempos ni los cambios políticos operados desde 1820 tuvieron su correlato en América: no sólo seguía predominando la incomprensión por parte del gobierno peninsular, sino que una pequeña minoría opuesta a la Constitución y asentada en puestos claves continuaba reteniendo las riendas del poder e imposibilitando la implantación en ultramar del nuevo orden. Además, las reclamaciones de los americanos para obtener una más equilibrada presen-

${ }^{22}$ Reflexiones, 1820, LAF-250. 
cia de delegados del nuevo mundo en las Cortes no condujeron a ninguna parte.

Detrás de ese problema de la representación indiana en Cortes, subyacía, según advierte Miranda,

una cuestión fundamental, de índole esencialmente política, la de la igualdad de derechos de peninsulares y ultramarinos; cuestión que constituía la entraña del llamado problema americano o a la cual se reducía en esencia éste [...] y, por lo tanto, cuestión en cuyo tornogirarían casi todas las demás, como giraron, en efecto, casi todas las otras que suscitaron colectivamente los diputados del nuevo mundo. ${ }^{23}$

Tal vez la importancia concedida a la discriminación de los americanos en el órgano legislativo se explique por su inserción en la corriente de afrentas inferidas por los europeos a los americanos, que tanto herian la susceptibilidad de los criollos. ${ }^{24}$ Así, el sistema de diputados suplentes que se utilizó en los ya remotos tiempos de Cádiz, y que luego volvió a aplicar la Junta Provisional en 1820, fue impug. nado desde el principio por los pa-

${ }^{23}$ Miranda, Las ideas, 1978, pp. 230-231.

${ }^{24}$ Villoro, El proceso, 1977, pp. 132-140, y López, La génesis, 1988, p. 56, donde se explica el desarrollo de la "conciencia criolla". Ésa cra indudablemente la sensibilidad que traslucía una representación dirigida al virrey de Nueva España, en 1821, en la que se reincidía en el agravio inferido a los americanos en este punto: "se les ha negado la representación que les toca. ¿Cómo, pues, querer que los nacidos en este continente pasen por la rebaja de las castas, cuando no sucede lo mismo en España que tiene muchos descendientes de los africanos?"; Siurob, Representación, 1821, LAF-769. triotas americanos, que consideraron ilegal la designación de esos representantes, puesto que no habían recibido el correspondiente encargo de sus provincias.

Menos aún satisfizo en ultramar la normativa que rigió para el nombramiento de los diputados propietarios, que fue tachada de discriminatoria porque proporcionaba a América un número de escaños insuficiente y excluía a las castas del derecho al voto. Ese fracaso en la aceptación de las propuestas de las Cortes sancionaba el naufragio de la solución de compromiso que había dado origen al decreto de 15 de octubre de 1810 , en virtud de la cual se aplazó para un futuro indeterminado la paridad en la representación parlamentaria de España y de ultramar. El problema, tal como lo entiende Rieu-Millán, estribaba en la imposible fusión de dos cuerpos tan heterogé. neos como España y América, sin que uno quedase subordinado al otro. 25

\section{LOS "ESPAÑOLISTAS"}

Pese a la negativa experiencia acumulada en los últimos tiempos, no falta-

25 Rieu-Millán, "Los diputados", 1988, pp. 53-72 (p. 62). Véase también Ferrer, La Constitucion, capítulo 7 , donde se trata extensamente de la representación americana en Cortes; Reyes, "Las Cortes", 1985, vol. I, pp. 263-316 (pp. 278.281 y $297-300$ ), que estudia los primeros problemas planteados en torno al número de representantes en Cortes que correspondía nombrar a América, y Hernández, "I Las Cortes", 1985, vol. I, pp. 317-718 (pp. 376-417, 521-530, 555.561 y 571-582), que recopila las extensas intervenciones de diputados españoles y americanos en las Cortes, en torno a la cuestión de que venimos ocupándonos. 
ban publicistas entusiastas partidarios de la unión con España. La consideración de las ventajas que, en su opinión, se seguirían para América de la revisión de los fundamentos del gobierno español les inducía a legitimar la dominación española: "bajo este benéfico sistema, esta reconciliación con la península será, más que dependencia real, una unión por recíproca conveniencia". 26

Además, antes de reivindicar la emancipación de América parecía obligado examinar si se hallaba en condiciones de gobernarse por sí misma. Ahora bien, atendida su baja demografia y constatado el carácter escasamente ilustrado de la población y el atraso en agricultura, artes, manufacturas y comercio - concluía uno de los detractores de la independencia-, "la América se halla muy distante del tiempo de su emancipación": era preciso olvidarse de este género de reivindicaciones, "que tanta sangre ha costado a nuestra querida patria", y acogerse a las posibilidades abiertas por la reimplantada Constitución de Cádiz. ${ }^{27}$

El mismo Carlos María de Bustamante, en el primer número de La Abispa de Chilpantzingo, reconocía la inmadurez de los ideales independentistas. Veía ante sí sólo "el embrión de un pueblo libre", que necesitaba avanzar un largo trecho antes de alcanzar la meta soñada: "témome mucho que, prevenido con estas disposiciones pésimas se nos forme un mosaico deforme de legislacion y gobierno". ${ }^{28}$

\footnotetext{
26 J. V:, Sobre, 1820 , LAF-261.

27 Breves, 1821, LAH-253.

${ }^{28}$ La Abispa de Chilpantzingo, núm. 1, LAF206.
}

En abierta discrepancia con esos juicios, y a notable distancia en el tiempo, José María Luis Mora fundamentó el derecho del pueblo mexicano a constituirse como nación independiente en su madurez histórica, que le concedía "bastante fuerza para subsistir por sí mismo, no necesitado ya del apoyo que le había prestado su metrópoli". Y, al definir las rémoras que incapacitaban a los pueblos para el acceso a la autonomía -lastres de los que, según Mora, México se había desprendido-, precisaba:

su debilidad, un terreno muy limitado, la falta de industria o de capitales, las producciones del país desconocidas o todavía no apreciadas en el resto del globo; pero más que todo su despoblación y escasez de luces.

A los ojos de Mora, la confluencia de esos factores en 1810 no desembocó en la independencia porque el "poder moral" - "el convencimiento de las ventajas de la independencia y el deseo de obtenerlas" - no era entonces sino patrimonio de unos pocos. Se hizo precisa la espera hasta 1821 porque "entonces aun la clase ínfima del pueblo conocía, apreciaba y deseaba los bienes consiguientes a la inclependencia". ${ }^{29}$

Eran también comunes las advertencias acerca de los amargos frutos que producía el árbol de la independencia: ${ }^{30}$ voz ésta "seductora", arrai-

\footnotetext{
${ }^{29}$ Mora, "Catecismo", 1985, Historia Constitucional, vol. II, pp. 307.351 (p. 313).

${ }^{30}$ Independencia, 1820, LAF-142. El tono excesivo de este folleto, que contenía bastantes afirmaciones peregrinas, mereció una réplica
} 
gada "en la imaginacion de hombres inconsiderados o falaces"; 31 política aquélla de la que

resulta que la masa general del Estado, para libertarse de los tiranos sin concepto que la oprimen, muda de mandantes por el camino de la violencia, hasta que viene a caer bajo la esclavitud de un solo hombre atrevido y mañoso que supo hacerse dueño de la fuerza armada. 32

Hubo polemistas que rebajaron a los partidarios de la independencia a la categoría moral de "criminales y delincuentes", infieles al juramento de observancia de la Constitución española, y desagradecidos - "ingratos hijos, prostituidos y espurios" - a los sacrificios prodigados por España para la conservación y enriquecimiento de sus posesiones ultramarinas. ${ }^{33}$

Algunos de los partidarios de la pervivencia del dominio español proponían una profundización en el concepto de libertad que previniera la comisión de ulteriores abusos por par-

contundente: J. B. M., Verdadera, 1820, LAF144.

31 Independencia, 1820, LAF-142.

32 Ibid.

${ }^{33} \mathrm{La}$ indepencia, 1821, LAF-257. Las duras descalificaciones de este folleto suscitaron inmediatas réplicas, incluso de los sostenedores de los intereses de España: "olvidad el espíritu que respira ese papel titulado La independencia. Su contenido os debe desengañar de que su autor no merece concepto alguno, y la mayor prueba que os puedo dar es, aseguraros del general desagrado que ha causado entre los europeos, quienes lejos de abrigar las ideas que en él se indican, desearían demostraros con hechos positivos que su afecto a vosotros es sincero, que su único anhelo es el de restablecer el orden...", M. J. V., El amigo, 1821, LAF-253. te de los nuevos dueños de la situación: y es honrado reconocer, aun admitiendo la impopularidad de la tesis antiindependentista, que el tiemporeveló certero este tipo de advertencias, fundadas en un dicho de la sabiduría popular entonces común en México: "no hay peor cuña que la del mismo palo".

Preocupaba también la dificil sujeción, a un mismo centro de poder, de territorios muy dilatados. Uno de esos autores "españolistas" enfilaba sus críticas a "la astuta pluma del sofista Juan Jacobo Rousseau", cuyos escritos habían llegado a configurarse como referencias obligadas para exaltarlos o para combatirlos:

este impío, en su Pacto social, enseña que en tratándose de libertad e independencia, una provincia no debe sujetarse a otra, ni una ciudad a otra ciudad: cada una debe ser independiente y erigirse autoridades a su arbitrio; porque no encuentra razón para que un pueblo grande reconozca superioridad a otro cuando todos tienen en sí libertad e igualdad de derechos para hacerse sociedad sin dependencia ajena, cuya dependencia tiene siempre el carácter de humillación. ${ }^{34}$

La vertiente intimidatoria era muy del gusto de los publicistas inclinados en contra de la independencia que, una vez y otra, insistían en trazar cuadros cargados de sombras y de ame. nazas. Sólo que, en ocasiones, la naturaleza de esos supuestos peligros permanecía sin develarse. ${ }^{35}$

${ }^{34}$ Independencia, 1820, LAF-142.

35 Para ejemplificar este tipo de argumentaciones, reproducimos un pasaje extmído de un 


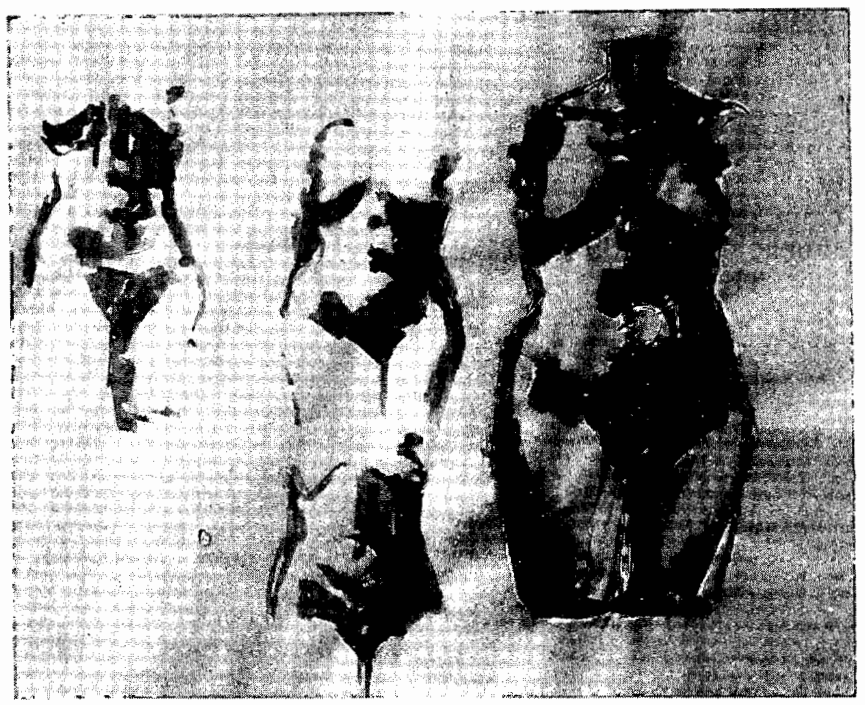

Por unánime que fuese la reivindi. cación de independencia-sostenía el irónico autor de Ventajas de la independencia-, 36 apenas nadie llegaba a calibrar sus graves consecuencias a corto plazo: entre ellas, la necesidad de reforzar con hombres, armas y construcciones las extensas fronteras de la nueva nación.

Los negros presagios sobre el futuro de una América emancipada, que se preveía irremediablemente envuelta

impreso citado ya anteriormente ( $L a$ independencia, 1821, LAF-257): "un enemigo más poderoso os asecha que aguarda vuestro triunfo para reduciros a mas dura y penosa esclavitud: ellos os harán arrastrar verdaderamente la cadena y con vuestro mismo oro labrarán los grillos que os sujetarán para siempre".

${ }^{36}$ A. J. F., Ventajas, 1821, LAF-442. en la anarquía, venían arropados de modo ocasional con consideraciones acerca del inmediato presente: el relevo del "incauto" Apodaca y la presencia en el virreinato del "prudente y benéfico" O'Donojú aconsejaban deponer posturas rupturistas y entablar un confiado diálogo con ese "agente del actual gobierno de España, liberal por esencia, y que tan generoso se muestra espontáneamente con nosotros" ${ }^{37}$ Ahora bien, muchos de quienes ensalzaban a O'Donojú abogaban por la separación: una independencia pactada y obtenida sin el recurso a las armas, pero independencia sin paliativos, por más que se invitara a los es-

37 Noticioso General, 27, agosto, 1821, núm. 103, LAF-126. 
pañoles a trabajar en la inminente regeneración de un país asolado por las guerras.

Más común era el punto de vista de los que, compartiendo el aprecio de la obra política llevada a cabo en América por España, entendían que era viable su culminación sin el trauma del rompimiento. Más aún,

un sistema de gobierno sabio, justo y equitativo acababa de abrir las puertas de par en par a la común felicidad, quitando las trabas que la oprimían, dando energía al cuerpo político del Estado y animando la industria por medio de una libertad absoluta a todos los ramos de ella. 38

Eran, en consecuencia, tiempos de esperanza porque la virtualidad de las instituciones políticas de raigambre liberal aseguraba la equidad, contribuía a la reconciliación y desterraba los viejos abusos. En función de estas premisas, los promotores de la independencia venían denunciados como facciosos y nostálgicos de la opresión; con Iturbide a la cabeza -el "falso Iturbide"-, de quien se recordaba su anterior actuación "tan impolítica y tan bárbara", sus irregularidades administrativas y su brutalidad:

ino es verdad que el que ahora quiere hacer el papel de héroe de la independencia es el mismo que en menos de dos horas hizo derramar a balazos la sangre de más de ciento y cincuenta desgraciados que querían lo mismo, dejando inundado en sangre el Valle de Santiago, teatro horrible de esta inhu-

${ }^{38}$ Liberales, 1821, LAF-439. mana carnicería, y esto a sangre fría y sin permitir que estos infelices recibieran los auxilios de la religion, que ahora este hipócrita dice viene a defender? ${ }^{39}$

El descrédito que se quería arrojar sobre los caudillos de la emancipación corría parejo al empeño por destacar los lazos comunes a europeos y americanos, que constituían el fundamento de la común felicidad:

tengamos presente que europeos y americanos todos somos españoles, dependemos de una nación grande y generosa, que profesamos una misma religion e idioma, que nuestros intereses están íntimamente enlazados, que hemos jurado ante el Omnipotente observar la Constitución, y ser fieles al mejor de los monarcas, que el augusto Congreso de Cortes se compone de españoles de ambos mundos, a quienes hemos conferido nuestros poderes, y que ellos promoverán cuanto convenga a la felicidad nacional. ${ }^{40}$

Quienes defendían estos criterios solian encomiar la figura de Apodaca - "un virrey íntegro, justificado y exactísimo en el cumplimiento de sus deberes"-, y no escatimaban alabanzas a su celo en el desempeño del cargo, al tiempo que vilipendiaban el plan sedicioso de Iturbide para "proclamar una independencia falaz e imaginaria". 41 Por lo demás, la conducta y las resoluciones de Ruiz de Apodaca "para oponerse a las criminales ideas del coronel Agustín de Iturbide y sus partidarios",

$39 \mathrm{bid}$.

${ }^{40}$ M. J. V., El amigo, 1821, LAF-253.

41 "Un incógnito", Advertencias, 1821, LAF253. 
recibieron la aprobación del propio Consejo de Estado en el mes de junio de 1821.42

Sin embargo, el irregular relevo de Apodaca por Novella, en julio de 1821, "sorprendió a México, llenando de amargura a todo hombre de juicio y prudencia"; 43 causó irreparables daños al gobierno español que, tras ese acontecimiento, se vio privado de legitimidad, ${ }^{44} \mathrm{y}$ dio alas a renovados intentos autonomistas por parte del Ayuntamiento capitalino, que reclamó para sí el ejercicio de la soberanía. ${ }^{45}$

La proclama que, con el título "El nuevo virrey a los mexicanos" redactó Novella el 12 de julio, tampoco consiguió disipar la desconfianza que en muchos inspiraba el peculiar procedimiento de su acceso al poder: la necesidad que parecía impulsar a Novella a justificar su presencia en el cargo que hasta entonces había desempeñado Apodaca restaba credibilidad a sus intenciones, por más que enfatizara su "amor y respeto a las sabias leyes que hoy felizmente nos rigen", y recordara "las pruebas más completas de subor-

42 Noticia, 1821, LAF-207.

i3 El apuntador, 1821, LAF-222; cit. en Ocampo, Las ideas, p. 170.

44 Ejército Imperial Mejicano de las Tres Garantías, núm. 11, 13 julio 1821. El primer número de Busca Pies tildaba de "cómico" al gobierno establecido por Novella, que sólo de un modo temerario y terco podía pretender resistir al "gobierno legítimo de la América septentrional [...], constituido por los jefes del Ejército Imperial Mexicano de las Tres Garantías", Busca Pies, núm. 1 (García, "La prensa", vol. vi, t. 2, p. 573).

${ }^{45}$ Representación, 1821, LAF-395, reproducida en Lemoine, "La revolución", vol. Iv, pp. 525.527. dinación y respeto" que había dado en el desempeño de sus tareas como subinspector general de Artillería y gobernador de la plaza. ${ }^{46}$

Más aún: las referencias al "misterioso suceso de la noche del 5 del corriente", que había culminado en su designación como primera autoridad del reino, resultaban particularmente desacertadas al ser presentado aquel acontecimiento como ocasión de que "la emulación indiscreta de algunos, la necedad de otros y la astucia de nuestros enemigos" ${ }^{\prime 7}$ se sirvieron para desprestigiar la figura de Novella.

La vana apología de sí mismo y la autocomplacencia en su personal valia, supuestamente refrendada por la experiencia -"el yunque [donde] han de estrellarse los martillos de la detracción"-, acababan de rematar el mal efecto de un documento redactado con tan notable torpeza.

La necesidad de colmar ese vacio de poder legal indujo a un "Ciudadano Español" a elaborar un plan que sometió a la Diputación provincial de México: solicitaba en él que no se aceptara la renuncia de Apodaca - "porque es imposible encontrar otro en quien concurran las cualidades de general con las prendas de un político"- y que, para atender el "negocio de los negocios", se reuniera un Congreso en México con los diputados recién elegidos para las Cortes españolas con la finalidad de determinar la voluntad de la nación: la unión con España o la inclependencia. ${ }^{48}$

${ }^{46}$ Novella, El nuevo, 12 julio 1821 , LAP- 424.

47 Ibid.

48 "El ciudadano español", El negocio, 1821, LAF-127. 
Incomunicado con Veracruzy consciente del progresivo deterioro de la resistencia realista, Novella publicó una violentísima proclama "a los egoístas de todas clases, condiciones y estados", que traducía un íntimo desasosiego y la convicción de que eran muy pocas las personas en que podía depositar su confianza. ${ }^{49}$

Los apologistas de la causa española, aun conscientes de la fragilidad de su postura, incomodada por la crisis en el mando virreinal, se esforzaban en probar la legitimidad de la conquista de México, sistemáticamente puesta en entredicho por el bando in-

49 Vale la pena reproducir íntegro el texto de este documento: "vuestra criminal conducta no se oculta al gobierno: veo con horror que unos os habéis ausentado de la capital y escondido en los pueblos de su circunferencia; otros en vuestras casas, y algunos os habéis acogido a la sombra de nuestros enemigos. No contentos con este proceder tan inicuo, disparáis cartas a los que llamáis vuestros amigos convidándolos a obrar como vosotros; les aumentáis la fuerza de nuestros contrarios; os pintáis como se os antoja, ya para atemorizar, ya para confiar en su conducta; todo, todo es obra de vuestra cobardia, de vuestra avaricia y egoísmo: pues calculasteis muy mal, estáis proscritos por todos los hombres, porque perdisteis el carácter de tales; volved a vuestro juicio, y tomad una resolución, ¡miserables! Yo no os llamo porque desconfio de vosotros; pero sí que no perturbéis la marcha de los buenos, porque este proceder os tiene hecha la causa en todos tiempos, en todas circunstancias $y$ por todos los hombres, que conocen que sois de aquellos que no tienen más patria que querer conservarse a costa del sacrificio de sus semejantes: vedme, vedme combatido de tempestades con la frente serena arrostrando todo género de peligros: ¿y qué espero? la salvación del reino, sin más interés que el que digan algún día, cumplió su deber"; Novella, Proclama, 1821, LAF-424. El texto de la proclama se publicó también en territorio dominado por Iturbide, precedido de una introducción de- dependentista, al tiempo que enumeraban los "vicios capitales del sistema de la independencia": la usurpación de los derechos del rey español; la carencia de una "voluntad general" manifiestamente decantada en favor de la ruptura y de unas fuerzas armadas capaces de defender efectivamente la independencia nacional; la falta de dirigentes capacitados para regir los destinos de la nueva nación; la amenaza representada por el poderoso vecino del norte; el dificil hallazgo de un titular para la corona en el caso, más que probable, de que Fernando VII declinase la oferta... 50

En esa enumeración de obstáculos y calamidades que acechaban cada paso de la ruta emancipadora, era insistente el énfasis en los horrores de la anarquía, que había de ser evitada a toda costa: la amarga experiencia del levantamiento de Hidalgo - "Ia sangre que aún humea", "el luto, la orfandad que por todas partes se presentó a nuestros dolientes ojos"- obligaba a prevenir sucesivas erupciones de "un horrible volcán que amenaza envolvernos en nuevos desastres". 51

\section{LOS "RUPTURISTAS"}

Incomparablemente más decididos y abundantes eran los impresos en favor de la emancipación: las quejas pre-

dicada a desacreditar la figura de Novella y acompañado de numerosas y extensas notas con apostillas sobre las afirmaciones que en la proclama hacía Novella, J. N. T., A los señores, 1821, LAF-393.

${ }^{50}$ Colmena de las Abejas, núm. 3, LAf-416.

${ }^{51}$ El verdadero liberal, 1820, LAF-143. 
sentadas en las Cortes españolas por los diputados americanos, 52 el Plan de Iguala y los Tratados de Córdoba, proyectos, discursos y sermones, modestas aportaciones a la filosofia política... todo ello era trasladado por la prensa a conocimiento de la ciudadanía y contribuía a crear un clima de opinión que, aparentemente, reflejaba una "voluntad general" inclinada a la independencia: "faltando, pues, la confianza mutua, y siendo implacable hoy el odio de españoles y americanos, se ha roto para siempre el lazo que unía las colonias a la metrópoli", 53 al deshacerse el pacto que, por voluntad de ambas naciones -americana y española-, unía tradicionalmente en la persona del monarca español los territorios de una y otra orilla del Atlántico.

El gobierno de España había comprometido su legitimidad y pasado a la conceptuación de "despótico y tiránico" al actuar en beneficio exclusivo de "una sola clase", y dictar leyes y órdenes "contra la voluntad expresa de los pueblos $\mathrm{y}$, por consiguiente, contra el bien común". ${ }^{54} Y$ sus delegados en México habían contribuido a ese desprestigio, sosteniendo órganos de prensa embusteros, como la Gaceta del Gobierno de México ${ }^{55}$ y Noti-

52 Papel, 1821, LAF-955; Ramírez, Nada, 1821, LAF-254. Una consulta del Consejo de Estado, fechada el 11 de junio de 1821, recogía el rumor -al que no parecía conceder excesivo crédito- de que "los diputados a Cortes han traído instrucciones para arreglar el modo de verificarla [la emancipación]"; Noticia, 1821, LAF-207.

53 Infante, Solución, 1821, LAF-221.

54 Busca Pies, núm. 1, cit. por García, "La prensa", vol. vi, t. 2, p. 573.

${ }^{55} \mathrm{La}$ Gaceta del Gobierno de México prota- cioso General, "concediendo libertad amplia a sus autores para estampar en ellos cuantas imposturas y dicterios dicta la maledicencia", y restringiendo arbitrariamente "la libertad política de la imprenta, que disfrutábamos con arreglo a nuestro sistema constitucional". 56

gonizó el más importante duelo con los periódicos insurgentes (después con los trigarantes), y se configuró como instrumento de propaganda y defensa de la causa virreinal: a esa contienda ideológica y a la necesidad de neutralizar los efectos de la prensa enemiga quedaron supeditados los contenidos informativos (véase García, "La prensa", vol. v, t. 1, pp. 39 y 85). A pesar de los dicterios que por esta razón se atrajo la Gaceta, la realidad es que esa mediatización de las tareas periodísticas al servicio de objetivos partidistas se registró también, como era inevitable, en el bando independentista. Pese a los ataques que el Diario Politico Militar Meficano dirigia en este texto a la Gaceta, había disminuido para entonces la virulencia de las confrontaciones verbales, sobre todo de parte de los periódicos que promovian la independencia. La explicación que proporciona Tarsicio García es plenamente convincente: "acorde con el sentido de conciliación del Plan de Iguala, el periodismo trigarante no pudo ser de combate; es predominante en lo informativo. La justificación en la causa se argumenta tratando de no ofender a España; y no entra a la polémica que con insistencia trató de provocar la Gaceta de México [...] El contenido de la prensa trigarante se reduce en el campo ideológico a exponer las condiciones de la conciliación; de lo que era necesario ceder para evitar un mal mayor"; Garcia, "La prensa", vol. v, t. 1, pp. 41 y 65).

${ }^{56}$ Diario Político Militar Meficano, 1 septiembre 1821, núm. 1, cit. por García, "La prensa", vol. vi, t. 2, pp. 580-581. Miquel i Vergés llamó la atención, en su momento, sobre la peculiar orientación política de algunos artículos de este periódico, que exaltaban la labor de las Cortes gaditanas, objeto de tantas críticas entre los trigarantes; y de ahí concluía que su redacción parecía obedecer "al impulso de los ideales que iniciaron la contienda en 1810"; 


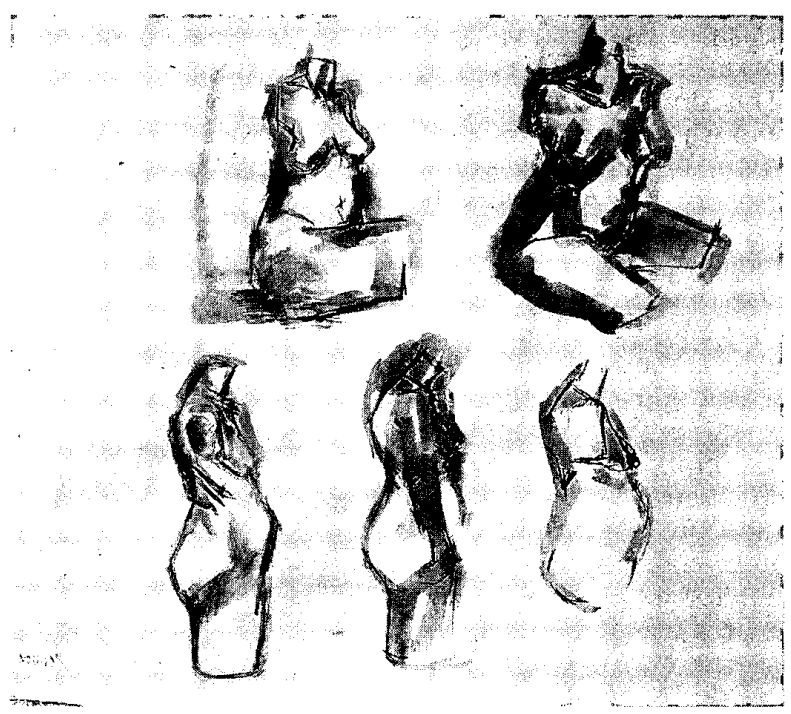

Según quienes invocaban la adhesión generalizada a la causa rupturista como razón para abandonar cualquier proyecto de continuidad bajo la dependencia española, los que se empeñaban en resistir eran apenas "un puñado de hombres casi ya sin recursos, sin opinión ni aceptación", por lo que

Miquel, La independencia, 1941, p. 308. En la misma obra encontramos una frase que recoge el mismo pensamiento con una mayor rotundidad, y que sugiere una interesante línea interpretativa pendiente de ulterior verificación: "son tantos los comentarios apologéticos a los mártires de 1810 que [...] se llega a pensar si la intención de algunos jefes no era la de enlazar el movimiento de Iturbide con el de Hidalgo" (ibid., p. 312). Sobre la aplicación en Nueva España de la libertad política de imprenta, véase Ferrer, La Constitución, capítulo 5, y Neal, "Freedom", 1966, pp. 87-112. la "independencia de nuestra América es un suceso indefectible que ha de verificarse tarde o temprano", 57 impulsado por "el voto unánime de sus naturales y habitantes", coincidentes todos en los anhelos independentistas: "criollos y europeos todos piensan y hablan en este sentido: todos anhelan por sustraerse del gobierno de Madrid". 58

La mención de una voluntad general obligaba, evidentemente, a tomar en cuenta la circunstancia de la diversidad de razas que cohabitaban en Nueva España. ¿Había de ser la reivin. dicación autonomista patrimonio co-

57 M. O. de T., Exhortactón, 1821, LAF-256.

${ }^{58}$ El Mejicano Independiente, t. I, "Introducción", 1821, Primero de la Independencia, cit. en García, "La prensa", vol. vi, t. 2, p. 440. 
mún?, ¿debían constituirse los criollos como abanderados de la causa?, y en el caso de que se aceptara esta última alternativa, equé papel correspondía a los indios y a las castas en el proceso de desvinculación de la metrópoli?, y, ¿qué trato dispensar a los españoles avecindados en México?

Obviamente encontramos diversidad de respuestas a estas interrogantes. Con el tiempo prevaleció, sin embargo, el protagonismo criollo, tendiente a configurar una sociedad análoga en todo a la colonial: eso sí, libre y purificada de las discriminaciones que durante tres siglos habían favorecido a los españoles peninsulares y cerrado muchas puertas a los americanos.

Las reflexiones teóricas concedían, en cambio, idéntica responsabilidad e idénticas oportunidades a todos los habitantes de Nueva España, llamados todos ellos a formar un cuerpo político capaz de integrar a indios y castas, y a españoles americanos y europeos. La inclusión de estos últimos, que se hallaba en la base del Plan de Iguala y de los Tratados de Córdoba, obedecía a razones que entonces parecían incontrovertibles. Así se explicaba el arcediano de Valladolid de Michoacán, Manuel de la Bárcena: "estando radicados aquí por sus destinos, por sus propiedades, y por sus enlaces, miran a la Nueva España como a patria suya, que ellos han elegido". 59

Rafael Dávila distinguía entre españoles amigos de la independencia y españoles que hostilizaban la reali-

${ }^{59}$ Bárcena, Manifiesto, 1821, LAF-442; Condumex, fondos Virreinales, XII-1, carpetas 17 24, núm. 1.248. zación del proyecto emancipador; y proponía que se recompensara a los primeros, mientras que se declaraba enemigo de los "muchísimos españoles que hablan de la independencia con desprecio", a los que se debería exigir un juramento para que, "eligiendo por su patria nuestro suelo, se comprometan a defenderlo de enemigos y guardar sus leyes". 60

Fernández de Lizardi expresó opiniones semejantes a las de Dávila, y manifestó sus dudas sobre la oportunidad de extender la garantía de unión a los españoles que no se habían mostrado adictos a la independencia y, como solía ocurrir con muchas de sus publicaciones, arrastró en la polémica a otros varios escritores, que coincidieron con él en una aplicación restrictiva de las promesas de Iguala. ${ }^{61}$

La apertura hacia los europeos imponía, forzosamente, un rechazo del primer movimiento insurreccional, "marcado con las señales más funestas", que presagiaba acontecimientos desastrosos como los "que han asolado nuestra tierra, y arruinado un sinnúmero de fortunas" ${ }^{62}$ En consecuencia, la revolución de 1810 no podía ser tachada sino de desorganizada y anárquica, "impolítica y desastrada", y contemplada con hostilidad por los artífices del renovado impulso independentista, que nada tenían en común con los impulsores de los desórdenes de la anterior década: los diri-

${ }^{60}$ Dávila, La verdad, 1821, LAF-257 cit. en Ocampo, Las ideas, p. 184.

${ }^{61}$ Ocampo, Las ideas, pp. 184-185.

62 El Mejicano Independiente, t. I, "Introducción", en García, "La prensa", vol. vi, t. 2, p. 439. 
gentes de 1821 "son los mismos que justamente se opusieron y la sofocaron [la revolución de 1810], y por lo tanto no hay que esperar los mismos resultados".63

En ese sentido, el autor de Justicia de la independencia dirigía las siguientes reflexiones a los españoles europeos:

españoles europeos, la nación os jura no volverán a molestar vuestros oídos las espantosas voces que os afligieron en los tiempos primeros de nuestra insurrección. Nuestras lágrimas corrieron al par que las vuestras al contemplar delito tan enorme, y muchos de los nuestros libraron a costa de las suyas vuestras preciosas vidas del infernal cuchillo. Por ventura nuestra aquellos tiempos de horror desaparecieron para siempre: los americanos todos garantizan sobre la fe pública vuestra felicidad: uníos a nosotros por los más indisolubles vínculos; vuestra patria no debe ser aquella que simplemente os vio nacer: este nombre debéis sin duda concederlo a aquel país que os favorece con su benigno influjo, y que os ha dado cuantas comodidades disfrutáis. Sí, españoles: contribuid a nuestra felicidad; la América soberana es, puede dar cuanto jamás podría daros la Europa toda; tranquilizad vuestros ánimos; reflexionad con atención sobre vuestro verdadero interés; no cerréis los ojos para no ver los repetidos ejemplares de generosidad y virtud que diariamente os presentan los ejércitos americanos. Unión intima $\mathrm{e}$ indisoluble con vosotros; he aquí uno de sus más gloriosos empeños. ¿Será posible que vosotros mismos rompáis este vínculo de amor y gratitud

${ }^{63}$ El Mejicano Independiente, 2 junio 1821, en Garcia, "La prensa", vol. vi, t. 2, p. 520. con que la misma naturaleza os ha unido con nosotros para siempre? ${ }^{64}$

Por contraste, el Diario Político Militar Mejicano prorrumpía en elogios a los "héroes ilustres" de 1810, "las almas venerables de los Hidalgos, Allendes, y Aldamas, de los Morelos, Matamoros, $y$ Bravos", a quienes atribuía el mérito de haber asentado los cimientos de la independencia y a quienes estimaba como "compatriotas" del invicto Iturbide: por consiguiente, nunca habría motivos de cansancio para dejar de "bendecir vuestra resolucion en el grito de Dolores en 1810 , de reconocervuestro acendrado patriotismo, de elogiar vuestra heroicidad, y de inmortalizar vuestros nombres". ${ }^{65}$ Alabanzas éstas que necesariamente comportaban la conciencia de que España seguía siendo el enemigo contra el que los hombres de 1810 se habían batido y contra el que se hallaban en plena lucha los de la nueva generación emancipadora.

El mismo Iturbide, que nunca simpatizó con la causa insurgente, no pudo prescindir de la adhesión de sus caudillos supervivientes, auroleados de prestigio popular, y no dejó de reconocer -aunque en sordina-que la toma de conciencia por la emancipación se debía a la insurgencia de 1810.66

${ }^{64}$ Justicta, 1821, LAF-1.417.

65 Diario Político Militar Mejicano, 17 junio 1821 , cit. en García, "La prensa", vol. v, t. 2, p. 652. La misma actitud reivindicadora de las actuaciones de los primeros insurgentes puede apreciarse en un anónimo que apareció en 1821 : Carta, 1821, LAF-210, cit. en Ocampo, Las ideas, p. 164.

66 Véase García, "La prensa", vol. v, t. 1, p. 
Una postura intermedia, respetuosa con una y otra de las etapas de la independencia, era la sostenida por Francisco Luis Ortega en su melodrama México libre, donde ensalzaba las figuras de Hidalgo, Matamoros y Morelos, e incluía un cálido panegírico de la persona de Iturbide, activo, prudente, sabio y "acostumbrado al rudo afán". ${ }^{67}$

Pero la realidad, crudamente expuesta por Ernesto Lemoine, es que la incompatibilidad de planteamientos entre los hombres de 1821 y sus antecesores de 1810 impedía alumbrar un proyecto conjunto:

en aras de liquidar una situación insostenible, todas las fuerzas que entraron en juego "transaron", pero a sabiendas de que la dicotomía axial (1810 versus 1821) quedaba en pie, y que el conflicto habría de reanudarse desde el día siguiente al de la "liberación" de la capital. $^{68}$

Con frecuencia se pretextaban el "mal gobierno" y el despotismo, y lo irremediable de esos hábitos defectuosos, para justificar la necesidad de emprender una vida política propia, no mancillada por vicios tan arraiga. dos. ${ }^{69}$ Muchas veces se proponía la

66, que se vale del texto aparecido en $E l M$ Mejica no Independiente, 3 marzo 1821.

67 Ocampo, Las ideas, pp. 166-167.

${ }^{68}$ Lemoine, "1821", 1985, pp. 25-35 (p. 34).

69 Un escrito dirigido al secretario de la Gobernación de Ultramar por los diputados en Cortes de Nueva España, fechado el 8 de agosto de 1821, aludía explícitamente a esas deficiencias de la acción gubernativa de España en América como una de las causas de "los disgustos de nuestra patria": "el gobierno despótico, injusto y arbitrario que hubo y aún hoy existe de hecho en las Américas. Sus magistrados, sus independencia como si fuese un elíxir mágico que desterraría de una vez por todas la desidia del gobierno, la corrupción de los funcionarios, las discriminaciones raciales, la impiedad en que parecía empeñada en precipitarse España desde que penetraron en la península las ideas liberales... Y se otorgaba a la emancipación un significado fundacional -el de un nuevo nacimiento-, como si el pueblo mexicano resultara fruto de un embarazo que se había prolongado entre 1810 y $1821 .{ }^{70}$

Los "Escribanos Nacionales", que se decían respaldados por más de mil cuatrocientas personas de Puebla, reaccionaban contra la influencia de la Ilustración francesa en España y vituperaban a los "patriarcas de la incredulidad" -D'Alembert, Voltaire...-, con quienes se había aliado el conde de Arana para "acabar con la religión de J. C." y expulsar a los jesuitas .71

jefes y sus empleados, fueron y son los que han dado la ley; ésta estaba, y aún está, en su capricho, no en los códigos: se ha dicho por muchos de ellos públicamente y en todos tiempos, aquí nosotros somos los únicos legisladores". Delgado, España, 1950, vol. III, pp. 31-35 (p. 32), documento $\mathrm{v}$, "Escrito dirigido por los diputados a Cortes de Nueva España al secretario de la Gobernación de Ultramar".

${ }^{70} \mathrm{Esa}$ interpretación es refutada por Bernardino Bravo: "la verdad es muy distinta. Cuando adoptaron el constitucionalismo, en la época de la independencia, [los pueblos hispanoamericanos] eran países con trescientos años largos de historia"; Bravo, El Estado, 1992, p. 3.

71 "Los escribanos nacionales", Defensa de los padres jesuitas por los poblanos, Oficina de don Pedro de la Rosa, México, 1820, cit. en Bachman, "Los panfletos", pp. 526-527 y 529. Algunas noticias sobre los incidentes registrados en Puebla cuando Ruiz de Apodaca publicó el decreto de Cortes por el que se suprimía la 


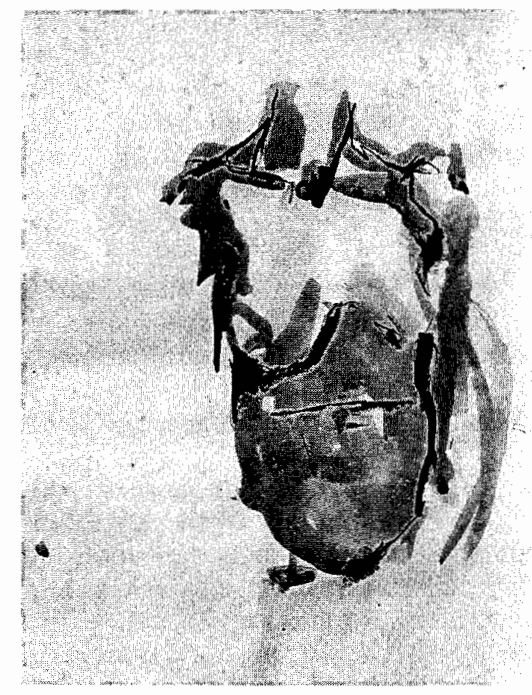

Manuel de la Bárcena aludía explícitamente al escándalo suscitado en Nueva España por la legislación religiosa de las Cortes del trienio, que chocaba con los hábitos mentales y las categorías de valores imperantes en el otro extremo del Atlántico:

acá no está la opinión tan avanzada como en la Europa, por eso la violenta extinción de tantos conventos religiosos, y el impolítico desafuero del clero, han escandalizado al pueblo, han irritado a los eclesiásticos, y han sido causas impulsivas del actual rompimiento. ${ }^{72}$

Compañía de Jesús, en Ferrer, La Constitución, pp. 82-84.

${ }^{72}$ Bárcena, Manifiesto, 1821, LAF-442; Condumex, fondos Virreinales, XLI-1, carpetas 17 . 24, núm. 1.248.

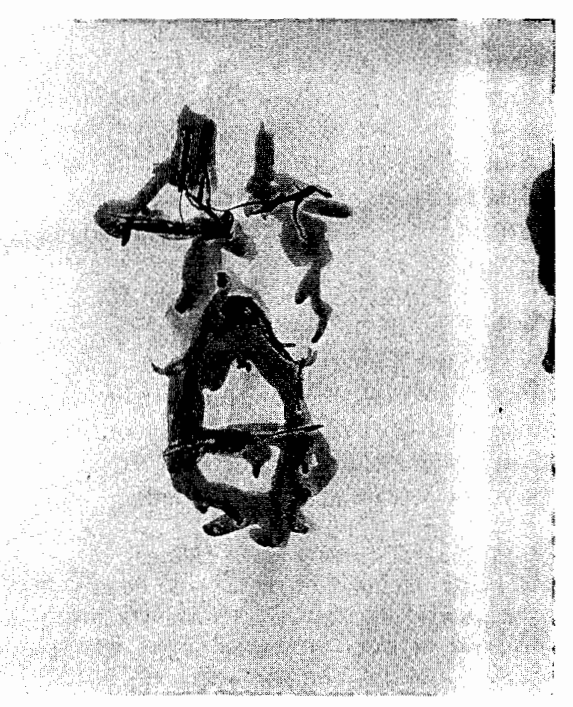

Era natural, por consiguiente, que Iturbide -defensor de la garantía religiosa- fuera exaltado por haber atraído las bendiciones del Cielo, y aplaudido como enviado de Dios, héroe de la religión, columna de la Iglesia, nuevo Moisés dador de libertad a un pueblo favorecido por la Providencia que, puesto a prueba, había sido esclavizado y oprimido. ${ }^{73}$

El análisis del mal gobierno era inseparable del balance económico de la colonización que, en el sentir de algunos críticos, sólo podía ser juzgado de un modo muy desfavorable, puesto que los beneficios de la empresa llevada a cabo por España en América habían sido patrimonio de unos pocos:

\footnotetext{
${ }^{73}$ Ocampo, Las ideas, pp. 56, 73 y 154.
} 
la nación española sólo indirectamente, por el momento y con daño imponderable de sus verdaderas riquezas, se ha aprovechado de las ventajas de la América mediante la circulación del dinero procedente de aquellos canales. Conviene inculcar al pueblo español esta verdad, que los comerciantes han procurado ofuscar por su interés, erigiendo en principio un error político perjudicial a la felicidad de ambos mundos [...] Los comerciantes gritan que se les escapa la América, objeto exclusivo de sus especulaciones, y que no pueden vivir sin que siga uncida al carro de la servidumbre. La nacionalidad, la fortuna y el bienestar de más de quince millones de almas deben, pues, sacrificarse a un puñado de monopolistas a expensas de la sangre de sus hermanos de ambos mundos. ${ }^{74}$

Ni siquiera la misma abundancia de metales preciosos que proporcionaba América había compensado los efectos negativos de su masiva afluencia a la península: "teniendo plata y oro con que comprar a los extranjeros abandonaron los talleres, que se arruinaron con el tiempo", sin que pudiera evitarse que ese flujo de riquezas acabara en manos extrañas. ${ }^{75}$

\section{CAUSA LIBERAL E INDEPENDENCIA}

En la percepción de algunos escritores, el mismo hecho de hallarse establecido en España un régimen liberal, si bien parecía precaver la recaída en los hábitos de mal gobierno, avalaba -o al menos favorecía- la escisión de

${ }^{74}$ Infante, Solución, 1821, LAF-221.

${ }^{75}$ Siurob, Representactón, 1821, LAF-769. las antiguas colonias pues, ¿cómo podría justificarse que un país regido por instituciones liberales enviara tropas para combatir opiniones parecidas a las que habían triunfado en la península?, ¿cómo imponer a los naturales de América "las mismas cadenas que los buenos españoles tratan de romper"?76

Los liberales españoles, aun partidarios de la unión, entendian que ésta no podía ser impuesta bajo coacción. Así se expresaba Flores Estrada en 1818:

mi deseo de que las Américas formen una misma nación con la España, debe entenderse siempre que sea compatible con la libertad, con los intereses, y aun con el voluntario consentimiento de aquéllas, y no de otro modo. ${ }^{77}$

Y un liberal mexicano, alineado con quienes así pensaban en España, expresaba su consternación ante el movimiento de Iturbide: "¿para qué pelear por la libertad y la independencia", si la Constitución de 1812 aseguraba que la nación española "es libre e independiente"? 78

La falacia parcial de esos argumentos estriba en que, al menos en el caso particular de Nueva España, el movimiento emancipador de los años veinte se arropaba, en parte, con una ideología antiliberal y, si se promovía para asentar un régimen constitucional, también eran perceptibles los recelos hacia las nuevas instituciones de mu-

\footnotetext{
76 Infante, Solución, 1821, LAF-221; Flores, Profecías, 1821, LAF-242.

77 Flores, Profecías, 1821 , LAF-242.

78 "Un incógnito", Advertenctas, 1821, LAF253.
} 
chos de sus partidarios. Lo que tal vez no entendian los liberales es que la lucha de los insurgentes por la independencia carecía, en buena medida, de aspiraciones políticas vinculadas al liberalismo, y conectaba más bien con la vieja aspiración de autogobierno.

Sí era más cierta la imposibilidad en que se veía España para disponer de tropas que combatieran en América: por lo demás, la experiencia de lo ocurrido en Cabezas de San Juan en enero de 1820 disuadía de preparar cuerpos expedicionarios acerca de cuya disciplina cabía abrigar serias dudas.

\section{IDEOLOGÍAS Y PRENSA}

Al analizar las publicaciones de la época tendientes a la ruptura con la metrópoli, llama la atención la falta de consistencia intelectual y de coherencia ideológica de que adolecen muchos de esos escritos: es frecuente que las mismas personas que difunden sus ideas al amparo de la libertad de imprenta (una libertad que aceptan y proclaman), pregonan la soberanía nacional y enfatizan la igualdad de todos ante la ley, califiquen de impías o disparatadas las pretensiones de las Cortes españolas de suprimir los fueros eclesiástico y militar, o de abrogar la exigencia civil de los diezmos.

Esas contradicciones se explican por la pervivencia en Nueva España, como en el resto de la América española, de las doctrinas escolásticas -ya arrinconadas en los países europeos más avanzados-, algunas de las cuales -las teorías pactistas, por ejemploproporcionaban una justificación del patriotismo criollo y de los movimientos emancipadores. ${ }^{79}$

Se tiene la impresión de que nos movemos en los límites entre antiguo régimen y modernidad - unas fronteras mury fluidas todavía- y de que los factores determinantes en la alternativa que se ofrecía a los novohispanos eran más de orden práctico que especulativo. En palabras de un "Joven Americano", "ninguna clase de gobierno puede hacer prosperar a las naciones americana y española, mientras la primera dependa de la segunda":80 sólo el autogobierno permitiría la defensa efectiva de los intereses americanos y el logro de "la perfección de las ciencias, de la agricultura, del comercio y de las artes". ${ }^{81}$

Desde la perspectiva de la modernidad sobresale la reiterada mención de los derechos del hombre - "generales y eternos"-para fundamentar el carácter ominoso $-y$ por ello transitorio- 82 de la dominación española, desconocedora de los presupuestos básicos de todo gobierno: "los pueblos pertenecen a sí mismos y contra su voluntad no pueden ser constituidos por otro, pues el derecho de legislar se concentra más, cuanto más se trabaja por arrancarlo". 83

79 Stoetzer, "Los países", 1989, pp. 329-330.

${ }^{80}$ A. de R., La necesidad, s.a., LAF-221. Nótese la precisión que el propio autor introduce más adelante sobre lo que él concibe como "nación americana": ésta "no puede ser otra cosa que el conjunto o reunión de todos los individuos nacidos y residentes en América, ya traigan su origen de África, de España o de Francia, etcétera."
81 Ibid.
82 J. M. C., Reflexiones, 1821, l.AF-1.417.
83 Ibid. 
También era común invocar la ruptura del pacto social que ligaba América con España (entendida la noción de pacto desde unos planteamientos acordes con la tradición escolástica): si los habitantes de aquella orilla del océano habian cedido parte de su libertad individual para constituir un gobierno que velara por su seguridad, fue precisamente "bajo la condicion de que este gobierno consulte únicamente a la pública utilidad". ${ }^{84}$ La tiranía y la opresión determinaban la disolución de tal vínculo, por lo que los ciudadanos quedaban liberados de la obligación de obedecer:

disolvióse por tanto justamente el vínculo de nuestra unión: devolvióse a la universalidad el derecho de gobernarse, y a ella únicamente pertenece establecer el gobierno que más le fuere conveniente. La utilidad pública clama enérgicamente por la absoluta emancipación e independencia de las Américas respecto de la antigua España; luego está demostrado con la mayor claridad, que la independencia de la América no puede ser más justa, aun cuando la España poseyese el más justo título para dominarla: 85

El obispo Antonio Joaquín Pérez encarna en su persona, tal vez como pocos, esa paradoja entre el apego a las viejas concepciones y la apertura a los nuevos tiempos. En el discurso que pronunció el 5 de agosto de 1821 en

${ }^{84}$ Justicia, 1821, LAF-1.417.

85 rbid. Otra mención explicita de la ruptura del pacto y del retorno a las Indias de la plena libertad para constituirse, en Bárcena, Manifiesto, 1821, LAF-442; Condumex, fondos Virreinales, XLI-1, carpetas 17.24, núm. 1248.
Puebla de los Ángeles para conmemorar la independencia, encontramos esa misma dualidad de principios: abrazaba la terminología en boga, al aludir a la ruptura del pacto con España, que restituía al "reino de Nueva España a la libertad que le concedió la naturaleza"; y, más adelante, lamentaba los ultrajes que la legislación constitucional deparaba a la religión. ${ }^{86}$

Precisado el concepto de indepen. dencia como

la facultad que tiene una nación para salir de la dominación de otra, entonces será buena o mala, según las circunstancias y ventajas que pueda sacar de ser gobernada por sí misma, o por la nación dominante; ${ }^{87}$

otra vez, por tanto, el mismo enfoque empírico a que aludíamos más arriba. Así quedaba justificada la independencia a los ojos de muchos, a quienes parecía imposible el funcionamiento en América del sistema de representación nacional previsto en la Consti. tución española. Los inconvenientes planteados por las excesivas distancias saltaban a la vista:

es muy díficil, y casi imposible, mantener el sistema representativo sobre el pie en que está: los diputados de España no tienen que dejar sus casas más que tres o cuatro meses al año, $y$ aun en este corto tiempo pueden desde Madrid atender a sus intereses; pero los de América han de abandonar sus familias, han de sufrir una ausencia de tres años a una distancia de casi medio mundo: agré-

86 Véase Pérez, Discurso, 1821, LAF-811; Condumex, Fondo LXII-2.

${ }^{87}$ J. B. M., Verdadera, 1820, LAF-144. 
guense los gastos de tan dilatado viaje, y la dificultad de los transportes por la suma escasez de la marina española; así, hemos visto en las actuales cortes que para la primera legislatura no tuvimos ningún diputado legítimo, y sólo un mezquino número de suplentes, faltos de poderes: para la segunda, de cincuenta y seis nombrados apenas seis habrán asistido; unos, por su poca salud o por su mucha edad, no se atrevieron a emprender tan larga peregrinación; otros se volvieron desde Veracruz; otros desde La Habana por temor a los corsarios o por falta de barcos...88

Ese pragmatismo inspira también algunos argumentos dirigidos a modelar la opinión, persuadiéndola de la utilidad que para España y sus posesiones americanas reportaba una pacífica desvinculación:

¿no sería mejor y le traería más utilidad a la península el dejar a la América independiente, aliada y amiga, sacando de ella cuanto provecho pudiera al tiempo de declararle su emancipación, que el perderla, conquistada por otra nación? ${ }^{89}$

Y TRAS LA INDEPENDENCIA, ¿MONARQUIA O REPUBLICA?

Análogas consideraciones de interés práctico se sitúan en la base de la casi general aceptación del régimen monárquico como el más indicado para una pacífica transición hacia el futuro nuevo Estado independiente: si bien

88 Bárcena, Manifiesto, 1821, LAF-442; Condumex, fondos Virreinales, XLI-1, carpetas 17 24, núm. 1248.

${ }^{89}$ J. B. M., Verdadera, 1820 , LAF- 144. el modelo republicano federal de los Estados Unidos de Norteamérica ejercía poderosa atracción, la forma política monárquica, por tradicional, parecía más indicada para México para serenar los ánimos inquietos de muchos ante el imprevisible rumbo del país, separado ya de España.$^{90}$ Sólo algunas voces discrepantes insinuaban las excelencias del régimen republicano:

cuál sea mejor género de gobierno, no es para tratarse con sofismas. Son muchas las razones que hay por una y por otra parte; y si el monárquico tiene excelentes fundamentos, quién sabe si sobrepujarán a los del republicano [...] La experiencia nos ha enseñado la preferencia de este género de gobierno respecto del monárquico [...] La razón no lo persuade menos porque siendo la virtud más díficil de practicar, mientras mayores sean las obligaciones anexas a su ejercicio, cuando vemos que es tan rara en los hombres corrientes, ¿será común en unos hombres que por su educación, por los objetos que los rodean desde su infancia, y por mil circunstancias, están, por decirlo así, casi necesitados a separarse, o cuando menos a desconocer el camino de la virtud? ¿Cuál es el resorte principal de una república? El amor a la patria; ¿y el de una monarquía? El honor. Aquél es una virtud; éste un fanatismo. ¿Cuál es más noble? ${ }^{91}$

90 Naturalmente, no faltaba quien opinaba exactamente lo contrario: "las monarquias no son compatibles ni con las luces, ni con los sentimientos, ni con circunstancia alguna de los pueblos americanos"; P. M., El Genio, 1821. Reimpreso en Puebla, LAF-260, cit. en Ocampo, Las ideas,p. 200.

${ }^{91}$ J. B. M., Verdadera, 1821, LAF-144. 
Teresa de Mier, ferviente republicano, adelantaba su convencimiento de que una monarquía en México sucumbiría necesariamente bajo el peso de la autoridad absoluta, y sostenía que los tres siglos de opresión monárquica ahorraban ulteriores razones en apoyo de sus tesis antimonárquicas. ${ }^{92}$

El Observador Independiente, aun reconociendo el gobierno republicano como "el más halagüeño para el hombre", no dejaba de reconocer los peligros que lo acechaban: la enorme extensión del territorio mexicano; la necesidad de una mayor instrucción entre los ciudadanos "por ser los que deben desempeñar los destinos"; el peligro de la propagación de conmociones, $\tan$ frecuentes en este tipo de regímenes, y la falta de garantías de los medios de coerción, muchas veces aplicados en daño de los virtuosos. ${ }^{93}$

Incluso personas como Lorenzo de Zavala, que más adelante destacarían por sus convicciones republicanas, compartieron el criterio de que debían sacrificarse momentáneamente las

pretensiones partidarias de los que querían la república, y de los que deseaban la monarquía absoluta. Todos los hijos del país se unían en el principio de nacionalidad; cada uno reservaba para después sus pretensiones diferentes. ${ }^{94}$

No parece desatinado pensar que la renuncia a la defensa de los postulados republicanos podía estar motiva-

92 Ocampo, Las ideas, pp. 200-201 y 203.

93 F. E. y A., El Observador Independiente, 1821, JAF-210.

${ }^{94}$ Zavala, Ensayo, 1969, pp. 87-88. da por la conciencia de que esa predilección era aún sentida por muy pocos. La amplísima difusión de la obra de Dominique de Pradt, que estimaba la monarquía constitucional moderada como la plasmación del espíritu político del momento $y$, consiguientemente, como el régimen más adecuado para México, contribuyó tal vez a enfriar los ánimos republicanos. ${ }^{95}$

\section{DESCENTRALIZACIÓN Y FEDERALISMO}

Tampoco era el momento de airear las aspiraciones federalistas. Por lo mismo que se aceptaba pacíficamente el sistema monárquico, se entendía que el entero territorio sometido a la autoridad de los antiguos virreyes constituía un todo que, como tal, había de configurarse como entidad autónoma. Incluso regiones como Nueva Galicia, que se convertirian en seguida en auténticos avisperos donde se desafiaba la supremacía de las instituciones centrales establecidas en la ciudad de México, acataban la "resurrección" del Imperio del Anáhuac para que, "haciéndose uno este reino con el de $\mathrm{N}$. E., quede separado perpetuamente de la antigua España". 96

En nombre de ese mismo buen sentido, la Gaceta Patriótica del Ejército Nacional -en su número 26 , del 21 de abril de 1820- disuadía del empleo

95 Ocampo, Las ideas, 1969, pp. 194-195.

96 Peimbert, Desafío, 1821, LAF-769. Conviene precisar que en esas fechas existian dos entidades con el nombre de Nueva España: desaparecido formalmente el virreinato por la Constitución, el virrey quedó convertido en capitán general del territorio abarcado por el an- 
de la fuerza para alcanzar los objetivos de autogobierno y recomendaba confianza en la resolución que adoptaran las Cortes: "entre tanto, procuremos acallar las pasiones y tratemos de inspirar confianza a aquellos con cuyo auxilio contamos para la grande obra de la conciliacion de ambos países". ${ }^{97}$ Naturalmente el parecer de la Gaceta Patriótica, que muchos juzgaban transigente en extremo, se prestaba a encendidas críticas que veían detrás de esa propuesta a

hombres débiles, sin energía, sin sentimientos, que, acomodando todas sus ideas al frío eterno que reina en la helada región de sus cerebros, no encuentran obstáculo en que un asunto como éste, por su naturaleza ejecutivo, siga los lentos y pesados trámites de un juicio ordinario. 98

tiguo virreinato de Nueva España, y jefe político superior de la Diputación provincial de Nueva España, que se correspondía con el antiguo reino de Nueva España y que incluía las provincias de México, Puebla, Oaxaca, Veracruz, Tlaxcala y Querétaro (por entonces se segregó la Diputación de Valladolid, que extendía su área de acción a Michoacán y Guanajuato). La presión de la delegación americana en Cortes logró que, en mayo de 1821, el Soberano Congreso dispusiera la concesión de diputaciones provinciales a todas las intendencias ultramarinas. Ese decreto de Cortes, fechado el 8 de ma. yo, llegaba sin embargo demasiado tarde, pues cuando su portador - el nuevo virrey $O^{\prime}$ Donojúarribaba a Veracruz con el texto de estas disposiciones, la casi totalidad de Nueva España se había separado de la obediencia del gobierno español.

${ }^{97}$ Gaceta Patriótica del Ejército Nactonal, 21 abril 1820, núm. 26, LAF-152.

${ }^{98} \mathrm{~J}$. M. C., Reflexiones, 1821, LAF-1.417. Parecido al punto de vista expresado en la Gaceta era el criterio del "Pensador Mexicano" que también encontró la correspondiente réplica: "¿es
Las circunstancias geográficas de la "duplicidad de continentes" y "la falta de proporción y de equilibrio" entre España y sus posesiones trasatlánticas constituían otros elementos de facto que recomendaban la correspondien. te separación de los órganos de poder al imposibilitar la "unión moral" entre uno y otro hemisferio; y es que -argumentaba el cubano Joaquín Infante- "las instituciones, para ser benéficas a un país es preciso que emanen de aquellos a quienes interesan, $y$ sean ellos mismos los ejecutores". 99

Si ese "monstruo político"100 llegó a durar trescientos años en contra del propio curso de la naturaleza, esa larga pervivencia era atribuible a la fuer. za de las armas, capaz de violentar las leyes naturales y de unir "bajo un cetro pueblos tan distantes, y tan heterogé.

justa, o no lo es, la independencia?: y por cuanto usted ha tenido ya el atrevimiento de escribir que es justa, pero que debe esperarse a que la determinen las Cortes, responda: ¿qué se deberá hacer en caso de que las Cortes o la de. nieguen, o no quieran determinarla?"; Iturbide, Carta, 1821, LAF-207.

99 Infante, Soluci6n, 1821, LAF-221.

${ }^{100}$ Así argumentaba Manuel de la Bárcena, a propósito del carácter "antinatural" de la dominación española en América: "una monarquía existente en las cuatro partes del mundo; una monarquía constitucional, compuesta de España, Canarias, las Américas, y las Islas Filipinas como partes integrantes es mil veces mas díficil de realizar que la república de Platón, es un despropósito, es un delirio, que sólo puede tener lugar en la cabeza de algún político febricitante: y los que quieren sostener tan disforme edificio, me parecen tan locos como aquellos jacobinos, que el año de mil setecientos noventa y tres, querían establecer la república universal del género humano". Bárcena, Manifiesto, 1821, LAF-442; Condumex, fondos Virreinales, XIJ-1, carpetas 17-24, núm. 1248. 
neos". ${ }^{101}$ Pero se trataba de una coacción éticamente injustificable, como también lo eran la anexión llevada a cabo por Cortés, contraria al derecho de gentes, y la donación de Alejandro VI realizada sin atender a que los papas carecían de dominio temporal sobre los reyes. ${ }^{102}$ En consecuencia, concluía el arcediano Manuel de la Bárcena, cuyo Manifiesto al mundo seguimos glosando, "no tuvo pues la península título legítimo para la adquisición de estos países; ni tampoco le tiene para retenerlos". 103

\section{IMPRESOS}

-A los señores oficiales y soldados del Ejército Nacional de las Tres Garantías, escrito por J. N. T., Imprenta Liberal de Troncoso Hermanos, México, 1821, Colección Lafragua (en adelante LAF) 424.

- Bárcena, Manuel de la, Manifiesto al mundo. La justicia y la necesidad de la independencia de la Nueva España, Imprenta Liberal de Moreno Hermanos, Puebla, 1821, LAF-442, y Centro de Estudios de Historia de México, Condumex, Fondos

101 Ibid. En el Desafio literario sobre la independencia de la América septentrional de la antigua España, de Juan Nazario Peimbert, se insistía en la oposición que el imperio español encontraba en la misma naturaleza: "según las circunstancias locales de la tierra; si la naturaleza nos ha dividido más de mil y quinientas leguas, nuestra América puede considerarse en su gobierno como un monstruo sin cabeza ¿Cómo podrá ser un rey padre de sus pueblos, si se hallan tan distantes de su tutela?"

102 Bárcena, Manifiesto, 1821, LAF-442; Condumex, fondos Virreinales, XLI-1, carpetas 17-24, núm. 1248; J. M. C., Reflexiones, 1821, LAF-1.417 y Justicia, 1821, LAF-1.417.

103 Bárcena, Manifiesto, 1821, LAF-442; Condumex, fondos Virreinales, XLI-1, carpetas 17 24, núm. 1248.
Virreinales, XIJ-1, carpetas 17-24, núm. 1.248.

-Breves reflexiones sobre la independencia de América, Oficina de los ciudadanos militares don Joaquín y don Bernardo de Miramón, calle de Jesús núm. 16, México, 1821, LAF-253.

- Carta de un filósofo sobre los últimos acaecimientos políticos, Imprenta Imperial, México, 1821, LAF-210.

-Dávila, Rafael, La verdad amarga, pero es preciso decirla, núm. 6, Imprenta Americana, México, 1821, LAF-257.

-"El Americano Liberal, J. V.", Proclama de un americano a los insurgentes y demás habitantes de Nueva España, Imprenta de don Alejandro Valdés, México, 1820, LAF-253.

-El amigo de españoles americanos $y$ europeos, escrito por M. J. U. , Oficina de D. J. M. Benavente, México, 1821, LAF-253.

- El Apuntador. Verdades en camisa o apuntes sobre la alteración de humores que padeció el cuerpo político del virrei. nato de México con motivo de la fiebre malignay contagiosa de que murió aquel gobierno, Imprenta de Mariano Ontiveros, México, 1821, LAF-222.

-"El Ciudadano Español", El negocio de los negocios. Representación urgentísima que dirige un ciudadano a la excma. Diputación Provincial de México, Oficina del Gobierno, Puebla, 1821, LAF-127.

- El Genio de la Libertad (a los cizdadanos de las provincias de Guatemala), escrito por P. M., Imprenta Americana, México, 1821. Reimpreso en Puebla, LAF260.

-El Observador Independiente, escrito por F. E. y A., Imprenta del ejército Imperial Mexicano, 1821, LAF-210.

El Verdadero Liberal. Paz, unión, justicia y constitución, Oficina de don José María Betancourt, calle segunda de la Monterilla, núm. 7, México, 1820, LAF-143.

-Exhortación cristiano-politica, dirigida a la capital del imperio mexicano, y a 
todos los que sostienen el partido nombrado la Integridad de las Españas, escrito por M. O. de T., Imprenta liberal de las Tres Garantías de don Cayetano Castañeda, Texcoco, 1821, LAF-256.

-Exposición presentada a las Cortes por los diputados de ultramar en la sesión de 25 de junio de 1821, sobre el estado actual de las provincias de que son representantes, $y$ medios convenientes para su definitiva pacificación; con una noticia de los trámites que la precedieron y motivaron, Imprenta de don Diego García y Campoy, Madrid, 1821, LAF-678. El texto de la exposición se publicó también en México:José Miguel Ramírez, Nada hay que esperar de España, o exposición que leyó el Sr. D. [...] en la sesión del 25 de junio de 1821, Imprenta Imperial de don Alejandro Valdés, México, 1821, Laf-254.

-Flores Estrada, Álvaro, Profecías políticas a favor de nuestra independencia. $O$ justificación de ella en razón al despotismo del gobierno español, sacada de la representación que hizo al rey de España en 1818, desde la ciudad de Londres, don Álvaro Flores Estrada, Imprenta (contraria al despotismo) de D. J. M. Benavente y Socios, México, 1821, LAF-242.

-Independencia. Amargos frutos que produce este árbol,Oficina de don Juan Bautista Arizpe, México, 1820, LAF-142.

-Infante, Joaquín, Solución a la cuestión de derecho sobre la emancipación de la América, por el ciudadano Joaquín. Infante, natural de la isla de Cuba, impreso en Cádiz, reimpreso en Puebla, y por su original en México, en la oficina de don José María Betancourt, calle segunda de la Monterilla, núm. 7, 1821, LAF-221.

-Iturbide, Agustín de, Carta de D. Agustín de Iturbide al "Pensador Mexicano", impresa en la oficina de don José María Betancourt, calle de San José el Real, núm. 2, México, 1821, LAF-207.

-Iusticia de la independencia, o apuntamientos sobre los derechos de los ame- ricanos, Oficina de don José María Betancourt, reimpreso en Guadalajara, México, 1821, LAF-1.417.

- La independencia, Oficina de don José María Betancourt, calle de S. José el Real núm. 2, México, 1821, LAF-257.

-La necesidad de la independencia demostrada por un joven americano, escrito por A. de R., Oficina de los ciudadanos militares don Joaquín y don Bernardo de Miramón, calle de Jesús núm. 16, México, s.a., LAF-221.

-Liberales, alerta, Oficina de don Juan Bautista de Arizpe, México, 1821, LAf439.

- Noticia de la mayorimportancia. Consulta hecha al rey de España por su Consejo de Estado sobre la independencia de América, Imprenta (contraria al despotismo) de D. J. M. Benavente y Socios, MéxiCo, 1821, LAF-207.

-Novella, Francisco, El nuevo virrey a los mexicanos, México, 12 julio 1821, LAF424.

_ Proclama a los egoístas de todas clases, condiciones y estados, Oficina de don Juan Bautista de Arizpe, México, 1821, LAF-424.

-Papel que la Diputación mexicana dirige al Excmo. señor secretario de Estado y del Despacho de la Guerra, impreso en Madrid por Ibarra, y en Puebla en la Oficina Liberal de Troncoso Hermanos, 1821, LAF-955.

-Peimbert, Juan Nazario, Desafio literario sobre la independencia de la América Septentrional de la antigua España. Por ellicenciado donJuan Nazario Peimbert, vicerrector del ilustre Colegio de Abogados de México, Oficina de don Mariano Rodríguez, Guadalajara, 1821, LAF-769.

-Pérez Martinez, Antonio Joaquín, Discurso pronunciado por el Illmo. señor doctor don Antonio Joaquín Pérez Martínez, obispo de la Puebla de los Ángeles, entre las solemnidades de la misa que se cantó en la catedral de la misma el día 5 
de agosto de 1821 acabada de proclamar y jurar la independencia del imperio Mexicano, Oficina del Gobierno Imperial, Puebla, 1821, LAF-811, y Centro de Estudios de Historia de México, Condumex, Fondo LXII-2, Impresos de la Independencia (Colección Martín Carracedo).

-Reflexiones importantes al gobierno constitucional de América, núm. 2, Imprenta de D. J. M. Benavente y Socios, México, 1820, LAF-250.

-Reflexiones sobre la independencia, por $\mathcal{J}$. M. C., reimpresas en Guadalajara, Oficina de don Mariano Rodriguez, 1821, LAF-1.417.

-Representación del excelentísimo ayuntamiento de México al comandante occidental de las armas de la misma ciudad, mariscal de campo don Francisco Novella, Imprenta del Gobierno Imperial, Puebla, 1821, LAF-395.

-Siurob, Juan José, Representación al Excmo. señor virrey sobre la independencia de América, Oficina de D. José María Betancourt, calle de San José el Real núm. 2, México, 1821, LAF-769.

-Sobre la suerte de las Américas, escrito por J. V., impreso en Madrid en la oficina de don Francisco Martínez Dávila, impresor de Cámara de S. M. Reimpreso en México en la de don Alejandro Valdés, 1820, LAF-261.

-"Un incógnito", Advertencias de un americano incógnito a sus conciudadanos, Imprenta de don Mariano Ontiveros, México, 1821, LAF-253.

-Ventajas de la independencia, escrito por A. J. F., Imprenta de don Mariano Ontiveros, México, 1821, LAF-442.

- Verdadera explicación de la voz independencia, J. B. M., Oficina de don Alejandro Valdés, México, 1820, LAF-144.

\section{HEMEROGRAFÍA}

-Colmena de las Abejas, núm. 3, LAF-416.
- Gaceta Patriótica del Ejército Nacio. nal, núm. 26, 21 abril, 1820, LAF-152.

-La Abispa de Chilpantzingo, núm. 1 , LAF-206.

-Noticioso General, núm. 103, 27 agosto 1821, LAF-126.

\section{BIBLIOGRAFIA}

-Artola, Miguel, La España de Fernando VII, Espasa Calpe, Madrid, 1968.

-Bachman, John E., "Los panfletos de la independencia", Historia Mexicana, vol. $\mathrm{xX}$, núm. 80, abril-junio de 1971.

-Bravo Lira, Bernardino, El Estado constitucional en Hispanoamérica 1811. 1991. Ventura y desventura de un ideal europeodegobierno en el nuevo mundo, Escuela Libre de Derecho, México, 1992.

-Comellas, José Luis, "El trienio liberal (1820-23)", en Historia General de España y América, Rialp, Madrid, 1981, vol. XII.

-Costeloe, Michael P., La respuesta a la independencia. La España imperial y las revoluciones hispanoamericanas, 1810 . 1840 , Fondo de Cultura Económica, México, 1989.

-Delgado, Jaime, España y México en el siglo $X I X$, Consejo Superior de Investigaciones Científicas, Madrid, 1950, vol. III.

- Ferrer Muñoz, Manuel, La Constitución de Cádizy su aplicación en la Nueva España (Pugna entre Antiguo y Nuevo Régimen en el virreinato, 1810-1821), Instituto de Investigaciones Jurídicas-Universidad Nacional Autónoma de México, México, 1993.

-García Díaz, Tarsicio, "La prensa insurgente", en Octavio Hernández (comp.), La república federal mexicana. Gestacion y nacimiento, 8 vols., Departamento del Distrito Federal, México, 1974, vol. vI, t. 2.

-Gil Novales, Alberto, El trienio liberal, Siglo Veintiuno de España Editores, Madrid, 1980. 
-Hernández Sánchez, Alejandro, "Las Cortes de Cádiz y las actuaciones de los diputados americanos", en VV. AA., Los derechos del pueblo mexicano. México a través de sus constituciones, Cámara de Diputados del Congreso de la Unión, LII Legislatura, México, 1985, vol. I (Historia Constitucional).

-Ladd, Doris M., La nobleza mexicana en la época de la independencia 1780 1826 , Fondo de Cultura Económica, México, 1984 .

-Lemoine, Ernesto, "La revolución de independencia, 1808-1821", en Octavio Hernández (comp.), La república federal mexicana. Gestación y nacimiento, Departamento del Distrito Federal, México, 1974, vol. IV, t. 2.

"1821: ¿Consumación o contradicción de 1810?", Secuencia, Revista Americana de Ciencias Sociales, núm. 1, marzo de 1985.

-López Cámara, Francisco, La génesis de la conciencia liberal en México, Universidad Nacional Autónoma de México, México, 1988.

-Miquel i Vergés, J. M., La independencia mexicana y la prensa insurgente, El Colegio de México, México, 1941.

-Miranda, José, Las ideas y las instituciones politicas mexicanas, $1^{a}$ parte (1521-1820), Insticuto de Investigaciones Jurídicas-Universidad Nacional Autónoma de México, México, 1978.

-Mora, José María Luis, "Catecismo político de la federación mexicana", en VV. AA., Los derechos del pueblo mexicano. México a través de sus constituciones, Cámara de Diputados del Congreso de la Unión, LII Legislatura, México, 1985, vol. II (Historia Constitucional).

-Neal, Clarice, "Freedom of the press in New Spain, 1810-1820", en N. L. Benson (comp.), Mexico and the spanish Cortes, 1810-1822, Institute of Latin American Studies, University of Texas Press, Austin/ Londres, 1966.
- Ocampo, Javier, Las ideas de un día. El pueblo mexicano ante la consumación de su independencia, El Colegio de México, México, 1969.

-Pérez Marchand, Monelisa Lina, Dos etapas ideológicas del stglo XVII en Méxicoa través de los papeles dela Inquisición, El Colegio de México, México, 1945.

-Rangel, Carlos, Du bon sauvage au bon révolutionnaire, Éditions Robert Laffont, París, 1976.

-Reyes Nevares, Salvador, "Las Cortes de Cádiz y las ideas políticas en México", en VV. AA., Los derechos del pueblo mexicano. México a través de sus constituciones, Cámara de Diputados del Congreso de la Unión, LII Legislatura, México, 1985, vol. I (Historia Constitucional).

-Rieu-Millān, Marie-Laure, "Los diputados americanos en las Cortes de Cádiz: elecciones y representatividad", Quinto Centenario, núm. 14, 1988.

-Rodriguez O., Jaime E., "The transition from colony to nation: New Spain, 18201821", en Jaime E. Rodríguez (comp.), Mexico in the age of democratic revolutions, 1750-1850, Lynne Rienner Publishers, Boulder/Londres, 1994.

-Rodriguez, Mario, "The 'american question' at the Cortes of Madrid", The Americas, núm. 38, enero de 1982.

-Sierra Brabatta, Carlos J., La Constitución Federal de 1824, Departamento del Distrito Federal, México, 1983 (Colección Conciencia Cívica Nacional).

-Stoetzer, Carlos, "Los países de la Plata (Argentina, Paraguay, Uruguay) y Chile", en VV. AA., La revolución francesa y el mundo ibérico, Turner/Sociedad Estatal Quinto Centenario, Madrid, 1989.

-Villoro, Luis, El proceso ideologico de la revolución de independencia, Universidad Nacional Autónoma de México, México, 1977.

-Zavala, Lorenzo de, Ensayo histórico de las revoluciones de Mëxico desde 1808 hasta 1830, Porrúa, México, 1969. 